Original Research Paper

\title{
Effect of Addition of Fermented Liquid on Silage Quality of Turi Leaves (Sesbania grandiflora) and Cassava Tubers (Manihot esculenta) as Fish Feed Ingredients
}

\author{
Daniel Wyclif Maatuil $^{1 *}$, Jacob L. A. Uktolseja ${ }^{1}$, Desti Christian Cahyaningrum ${ }^{1}$ \\ ${ }^{1}$ Fakultas Biologi, Universitas Kristen Satya Wacana, Salatiga, Indonesia.
}

\author{
Article History \\ Received : August $14^{\text {th }}, 2021$ \\ Reveised : August $30^{\text {th }}, 2021$ \\ Accepted : September $12^{\text {th }}, 2021$ \\ Published : September $21^{\text {th }}, 2021$ \\ *Corresponding Author: \\ Daniel Wyclif Maatuil, \\ Universitas Kristen Satya Wacana \\ Salatiga, Indonesia; \\ Email: \\ 412015012@student.uksw.edu
}

\begin{abstract}
Utilization of Turi leaves (Sesbania grandiflora) and cassava tubers (Manihot esculenta) as a protein source to replace some fish meal can be done by silage of the two ingredients. This silage fermentation process requires adding inoculum from the fermented liquid to obtain good quality silage. This study aims to determine the effect of fermented liquid on the quality of silage made from Turi leaves and cassava tubers for fish feed ingredients through parameters of Titration End Point and $\mathrm{pH}$ levels. The research treatment was the addition of fermented liquid for four days with a sugar content of $1 \%$ (CT4-1\%) in the treatment silage (S_CT4-1\%), compared to the initial silage (SA) and the negative control silage $(\mathrm{SKN})$. The results showed a significant $(\mathrm{P}<0.05)$ addition of CT4$1 \%$ fermented liquid, namely Titration End Point S_CT4-1\% a significant increase of $281.9 \%$ from $18.33 \mathrm{~mL}$ in SA to $70.00 \mathrm{~mL}$ in treatment. The $\mathrm{pH}$ condition significantly decreased from 5.35 in SA to 4.17 in the treatment. Titration End Point on SKN only increased by $90.9 \%$ from $18.33 \mathrm{~mL}$ to $35.00 \mathrm{~mL}$, with $\mathrm{pH}$ only dropping from 5.35 to 4.31 . Study concuded that CT4-1\% produced excellent quality silage of Turi leaves and cassava tubers based on TAT and $\mathrm{pH}$ levels. This quality can increase the chance of silage of Turi leaves and cassava tubers treated with CT4-1\% as a partial substitute for fish meal in fish feed manufacture.
\end{abstract}

Keywords: Fermented liquid, fish feed ingredients, inoculum, Turi leaf and cassava tubers silage.

\section{Pendahuluan}

Daun turi (Sesbania grandiflora) dan umbi singkong (Manihot esculenta) memiliki fungsi subtitusi sebagai bahan pembutan pakan ikan Aryani et al., (2018) menyatakan bahwa daun turi memiliki kandungan protein kasar sebanyak $31,29 \%$, lemak kasar $7,57 \%$, serat kasar $27,88 \%$, abu $7,34 \%$, dan bahan ekstrak tanpa nitrogen (BETN) $28,02 \%$. Sementara itu, umbi singkong per $100 \mathrm{~g}$ bahan memiliki kandungan kalori $146 \mathrm{kkal}$, protein 1,20 g, lemak 0,3 g, kalsium $33 \mathrm{mg}$, fosfor $40 \mathrm{mg}$, dan zat besi 0,7 mg (Wijayakusuma 2011). Penggunaan daun turi dan singkong sebagai sumber protein pakan ikan yang berasal dari tanaman mengandung antinutrisi seperti tanin dan asam fitat
(Panda et al., 2013). Selain itu, antinutrisi tersebut dapat dikurangi dengan fermentasi bakteri asam laktat (Setiarto dan Widhyastuti 2016) seperti pada pembuatan silase daun Turi dan umbi singkong (Fitri, 2013).

Silase merupakan hijauan makanan ternak (HMT) yang telah difermentasi, sehingga lebih kaya akan nutrisi, mudah dicerna oleh ternak dan tahan lama ketika disimpan (awet) (Prayitno et al. 2020). Silase memiliki fungsi dan bermanfaat untuk memenuhi kebutuhan pakan ternak, khususnya pada musim kemarau (Hertanto et al., 2018). Bahan baku silase dapat bersumber dari keragaman tanaman hijau, seperti limbah pertanian dan perkebunan dari jagung, daun ketela rambat dan singkong. 
Silase dibuat melalui proses fermentasi dalam kondisi anaerob. Dalam pembuatan silase inokulum berperan penting dan memberikan pengaruh terhadap kualitas silase (Ramli. 2014). Inokulum bertujuan sebagai agen fermentasi pada proses pembuatan silase, sehingga dapat disimpan tanpa merusak zat nutrisi yang terkandung di dalamnya. Inokulum yang digunakan dalam pembuatan silase tersebut biasanya merupakan kelompok bakteri asam laktat (BAL). Kelompok bakteri ini menghasilkan asam laktat dan bakteriosin yang dapat mencegah tumbuhnya mikroba dan patogen yang merugikan dalam proses pembuatan silase (Zakariah, 2014).

Menurut penelitian Fitri (2013) cairan terfermentasi daun turi (Sesbania grandiflora) dan umbi singkong (Manihot esculenta) secara signifikan meningkatkan kualitas silase sebagai inokulum karena mengandung bakteri asam laktat. Bakteri pada cairan terfermentasi secara umum berupa bakteri laktat efifitik yang berasal dari hijauan silase, seperti pada pembuatan silase rumput Timothy (Phleum pratense) dan rumput orchard (Dactylis glomerata) (Masuko et al., 2000) yang mempunyai kemampuan fermentasi lebih baik daripada bakteri inokulan buatan seperti Lactobacillus casei ketika diaplikasikan pada pembuatan silase alfalfa (Medicago sativa) (Oshima et al., 1997). Dalam hal ini pemberian cairan terfermentasi berpeluang besar meningkatkan kualitas silase, karena fermentasi asam laktat berjalan lebih baik.

Kualitas silase dapat diamati secara fisik dari warna, aroma, tekstur, juga secara kimia $\mathrm{pH}$ dan total asam tertitrasi (TAT) (Prayitno et al. 2020). Indikatornya dapat dilihat dari nilai $\mathrm{pH}$, dimana bila pH silase turun mendekati 4 menunjukkan kualitas silase sangat baik (Muck, 1998; Elfrina et al., 2010). Produksi asam laktat yang cukup banyak dapat diamati dari kadar TAT (Bhaskar et al., 2006), yaitu peningkatan TAT yang signifikan tinggi menunjukkan peningkatan produksi asam laktat yang tinggi. Selanjutnya, fermentasi asam laktat juga dapat menurunkan kandungan antinutrisi bahan yang difermentasi (Skrede et al. 2002). Keunggulan hasil fermentasi bahan baku tanaman sebagai pakan ikan belum ada informasi ilmiahnya, berkaitan dengan penggunaan konsentarasi cairan terfermentasi. Oleh karena itu, perlu dilakukan penelitiannya. Tujuan penelitian ini adalah menginvestigasi dan mendeskripsikan pengaruh penggunaan cairan terfermentasi terhadap kualitas silase berbahan dasar daun turi dan umbi singkong untuk bahan pakan ikan dengan parameter kadar $\mathrm{pH}$ dan TAT.

\section{Bahan dan Metode}

\section{Waktu dan Tempat}

Penelitian dilaksanakan pada bulan Januari sampai dengan bulan Maret 2020 di Laboratorium akuakultur (AU 11), Fakultas Biologi, Universitas Kristen Satya Wacana, Salatiga.

\section{Alat}

Penelitian ini alat yang digunakan adalah blender, kantong plastik bening, kantong plastik hitam, buret, botol gelap, Erlenmeyer $100 \mathrm{~mL} 6$ buah, $\mathrm{pH}$ meter.

\section{Bahan}

Penelitian ini bahan yang digunakan yaitu umbi singkong (Manihot esculenta), daun Turi (Sesbania grandiflora) segar yang ditemukan di area kota Salatiga, gula pasir merk Gulaku, dan air yang telah direbus, $\mathrm{NaOH}$, larutan indikator $\mathrm{PP}$, dan akuades.

\section{Pembuatan Cairan Terfermentasi}

Cairan terfermentasi dibuat dengan cara daun turi dan singkong yang telah dijemur dihaluskan dengan blender dengan perbandingan 7:3 dan ditambahkan air dengan perbandingan 1:5. Bahan yang sudah halus disaring, air hasil saringan kemudian ditambahkan $1 \%$ gula, lalu dimasukan dalam plastik bening dengan sedikit sisa udara dan dibungkus plastik hitam di bagian luar, lalu diinokulasi selama 4 hari dalam loker Laboratorium AU 11, Fakultas Biologi, Universitas Kristen Satya Wacana. Cairan terfermentasi ini diberi kode CT4$1 \%$.

\section{Pembuatan Silase Daun Turi dan Umbi Singkong \\ Pulp merupakan bahan dasar silase yang} dihaluskan. Pulp dalam penelitian ini dibuat dari campur umbi singkong dan daun Turi dengan perbandingan 7:3, kemudian dihaluskan dengan blender. Perlakuan dalam penelitian ini adalah penambahan cairan terfermentasi CT4-1\% pada silase perlakuan (S_CT4-1\%). Sebagai kontrol adalah silase awal (SA) dan silase kontrol negatif 
(SKN) yang masing-masing tidak diberi CT4-1\%. SA tidak diinkubasi, SKN dan S_CT4-1\% diinkubasi selama 6 hari dalam loker Laboratorium AU 11, Fakultas Biologi, Universitas Kristen Satya Wacana.

\section{Pengukuran TAT dan pH Silase}

TAT dan $\mathrm{pH}$ diukur pada masing-masing silase. TAT diukur dengan melakukan titrasi pada sampel dengan $\mathrm{NaOH}$ 0,1 $\mathrm{N}$ sampai $\mathrm{pH}$ mencapai 8 (Bhaskar et al., 2006). Pengukuran pH dilakukan dengan menggunakan $\mathrm{pH}$ meter.

\section{Analisis Data}

Penelitian ini menggunakan Rancangan Acak Lengkap. Perlakuan penelitian adalah pemberian cairan terfermentasi 4 hari dengan kadar gula $1 \%$ pada silase perlakuan (S_CT4-1\%), dan sebagai kontrol adalah silase awal (SA) serta silase kontrol negatif (SKN) dengan masing-masing unit percobaan diulang tiga kali. Data TAT dan $\mathrm{pH}$ dianalisis dengan Analisis Variansi Satu Arah dengan taraf nyata $\alpha=0,05$. Sebelum dianalisis, normalitas dan heterogenitas data diperiksa masing-masing dengan uji Levene dan ShapiroWilks. Uji posterior dilakukan dengan uji Tukey $(\mathrm{P}<0,05)$. Analisis data dilakukan dengan SPSS software for Window Release13.0.

\section{Hasil dan Pembahasan}

\section{Kadar pH Silase Daun Turi dan Umbi Singkong}

Silase yang telah diinkubasi selama 6 hari diukur kadar $\mathrm{pH}$ dengan menggunakan $\mathrm{pH}$ meter hasil dapat dilihat pada Gambar 1.

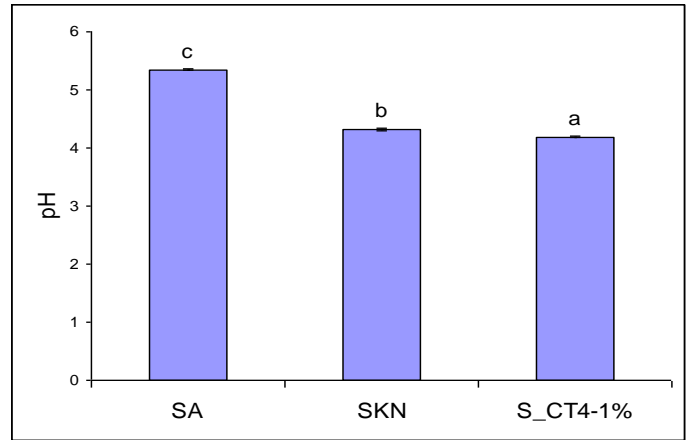

Gambar 1. Kadar pH (rata-rata \pm galat baku) silase awal (SA), silase kontrol negatif (SKN), silase cairan terfermentasi 4 hari dengan kadar gula 1\% (S_CT4-1\%) setelah enam hari diinkubasi pada suhu kamar.
Hasil penelitian menunjukan $\mathrm{pH}$ silase daun turi dan umbi singkong setelah fermentasi selama 6 hari ada pengaruh signifikan $(\mathrm{P}<0,05)$. Kadar $\mathrm{pH}$ silase perlakuan (S_CT4-1\%) signifikan sudah mendekati $4(4,19)$ dari $\mathrm{pH}$ semula 5,35 pada SA menunjukkan bahwa bakteri asam laktat (BAL) dalam cairan terfermentasi dapat bertumbuh dan mendominasi dalam silase (Muck, 1998; Elfrina et al., 2010). Pada SKN pH hanya turun lebih kecil sampai 4,31 masih di atas 4 yang menunjukkan BAL belum sepenuhnya dapat bertumbuh dan mendominasi dalam silase sebanyak yang dihasilkan oleh S_CT4-1\%. Menurut Jamaru et al. (2014) Nilai $\mathrm{pH}$ silase yang berkualitas baik yaitu mempunyai $\mathrm{pH} 3,5-4,2$. Berdasarkan hal tersebut nilai rata-rata $\mathrm{pH}$ yang dihasilkan S_CT4-1\% masih dalam kisaran kualitas baik sedangkan kadar $\mathrm{pH}$ SKN masih belum mencapai angka tersebut. $\mathrm{pH}$ yang rendah pada silase menandakan kandungan asam laktat yang tinggi (Kung dan Shaver. 2001).

\section{Kadar TAT Silase Daun Turi dan Umbi Singkong}

Silase yang telah diinkubasi selama 6 hari diukur kadar TAT dengan melakukan titrasi pada sampel dengan $\mathrm{NaOH} 0,1 \mathrm{~N}$ sampai $\mathrm{pH}$ mencapai 8 hasil dapat dilihat pada Gambar 2.

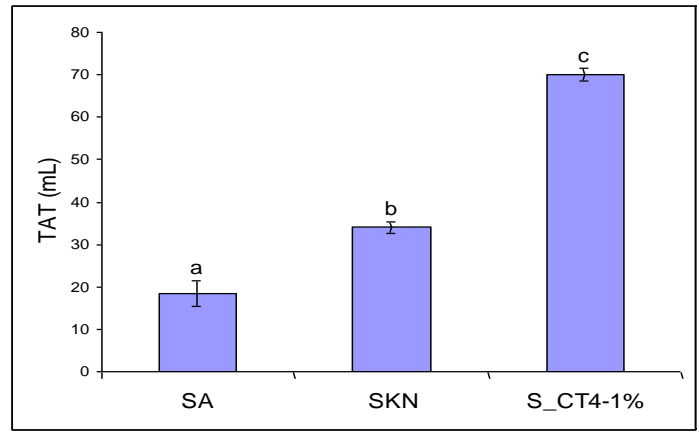

Gambar 2. Kadar total asam tertitrasi TAT (ratarata \pm galat baku) silase awal (SA), silase kontrol negatif (SKN), silase cairan terfermentasi 4 hari dengan kadar gula 1\% (S_CT4-1\%) setelah enam hari diinkubasi pada suhu kamar.

Pengukuran kadar TAT menunjukan peningkatan yang signifikan $281,9 \%$ dari $18,33 \mathrm{~mL}$ pada SA menjadi $70,00 \mathrm{~mL}$ pada S_CT4-1\%, dan naik lebih rendah sebesar $90,9 \%$ dari $18,33 \mathrm{~mL}$ pada SA menjadi $35,00 \mathrm{~mL}$ pada SKN. Jadi penambahan S_CT4-1\% secara nyata mempengaruhi kandungan asam laktat dalam silase 
sehingga bisa didapatkan kualitas silase yang baik. Asam laktat yang dihasilkan oleh BAL (bakteri asam laktat) dapat melawan bakteri patogen sehingga memungkinkan pengawetan protein (Zacharof \& Lovit 2012; Lelise et al. 2014). Penambahan CT4-1\% juga dapat mempercepat proses fermentasi karena BAL yang terkandung didalamnya lebih cepat beradaptasi dan memproses bahan utama yaitu singkong dan daun turi, karena CT4-1\% terbuat dari bahan dasar yang sama (Fitri, 2013). Berdasarkan kualitas silase yang dihasilkan, maka diduga asam laktat yang dihasilkan akibat penambahan CT4-1\% mampu mengawetkan protein silase dari degradasi bakteri Clostridium yang dapat tumbuh dalam kondisi anaerob pada silase.

\section{Kualitas Fisik Silase Daun Turi dan Umbi Singkong}

Hasil pengamatan silase daun turi dan umbi singkong setelah 6 hari inkubasi dalam loker yaitu adanya perubahan warna, aroma, tekstur, dan kontaminasi jamur.

Tabel 1. Karakteristik fisik silase daun turi dan umbi singkong setelah 6 hari inkubasi.

\begin{tabular}{cccc}
\hline Peubah & SA & $\begin{array}{c}\text { Perlakuan } \\
\text { SKN }\end{array}$ & S_CT4-1\% \\
\hline Warna & Hijau & $\begin{array}{c}\text { Hijau } \\
\text { kekningan } \\
\text { dan sedikit } \\
\text { coklat }\end{array}$ & $\begin{array}{c}\text { Hijau } \\
\text { kekuningan } \\
\text { dan sedikit } \\
\text { coklat }\end{array}$ \\
Aroma & $\begin{array}{c}\text { Aroma } \\
\text { daun turi } \\
\text { dan umbi } \\
\text { singkong }\end{array}$ & $\begin{array}{c}\text { Khas } \\
\text { fermentasi } \\
\text { asam laktat }\end{array}$ & $\begin{array}{c}\text { Khas } \\
\text { fermentasi } \\
\text { asam laktat }\end{array}$ \\
$\begin{array}{c}\text { Kontami } \\
\text { nasi } \\
\text { jamur }\end{array}$ & $\begin{array}{c}\text { Tidak ada } \\
\text { kontamin } \\
\text { asi }\end{array}$ & $\begin{array}{c}\text { Tidak ada } \\
\text { kontaminasi }\end{array}$ & $\begin{array}{c}\text { Tidak ada } \\
\text { kontaminasi }\end{array}$ \\
\hline Ketangan
\end{tabular}

Keterangan : SKN (silase kontrol), S_CT4-1\% (Silase).

Silase awal berwarna hijau difermentasi selama 6 hari menjadi hijau kekuningan dan sedikit kecoklatan. silase berkualitas baik adalah berwarna hijau kekuningan sampai hijau kuning kecoklatan tergantung materi silase, menghasilkan bau khas fermentasi asam laktat, silase berkualitas baik akan menghasilkan bau seperti susu fermentasi dikarenakan mengandung asam laktat, dan tidak ada kontaminasi jamur pada tiap silase (Saun et al. 2008 dan Prayitno et al. 2020).

\section{Penggunaan CT4-1\% dalam silase daun turi dan umbi singkong}

Hasil kadar $\mathrm{pH}$ dan TAT dengan perlakuan CT4-1\% dari penelitian yang dilakukan menunjukan perbedaan signifikan dari kadar $\mathrm{pH}$ dan TAT silase awal dan kontrol negatif. Kedua hasil menunjukan tingginya kandungan asam laktat yang ada di dalam silase ini sehingga dapat dikategorikan kualitas silase yang baik. Menurut penelitian Bhaskar et al. 2006 bahwa produksi asam laktat yang signifikan menunjukan kadar TAT yang signifikan tinggi.

Fermentasi oleh bakteri asam laktat dari CT4-1\% dapat meningkatkan kualitas nutrisi silase karena menghambat pengaruh antinutrisi bahan baku silase; meningkatkan ketercernaan protein, lemak, karbohidrat, serta meningkatkan pemanfaatan energi (Skrede et al., 2002; 2007), sehingga dapat diduga berdasarkan teori tersebut fermentasi asam laktat silase daun turi dan umbi singkong yang diberi CT4-1\% dapat meningkatkan ketercernaan protein, lemak, karbohidrat, serta meningkatkan pemanfaatan energi dari pakan ikan jika digunakan sebagai pengganti sebagian tepung ikan dalam pembuatan pakan ikan sehingga nutrisi pakan ikan berkualitas baik, dapat dicerna dan diserap dengan baik.

Kemampuan pengawetan protein, ketercernaan nutrisi, dan peningkatan pemanfaatan energi ini memperbesar peluang silase daun turi dan umbi singkong yang diberi CT4-1\% sebagai pengganti sebagian tepung ikan dalam pembuatan pakan ikan sehingga mengurangi biaya bahan baku dengan menggunakan bahan yang mudah didapatkan dan dengan harga yang sangat murah tapi tidak menghilangkan nutrisi dalam pakan.

\section{Kesimpulan}

Kesimpulan penelitian adalah penambahan cairan terfermentasi 4 hari dengan kadar gula $1 \%$ (CT4-1\%) menghasilkan kualitas silase daun Turi dan umbi singkong sangat baik berdasarkan kadar TAT dan $\mathrm{pH}$. Kualitas ini dapat meningkatan peluang silase daun Turi dan umbi sigkong yang diberi CT4-1\% sebagai pengganti sebagian tepung ikan dalam pembuatan pakan ikan. 


\section{Ucapan Terima Kasih}

Ucapan terima kasih disampaikan kepada Tuhan yang Maha Esa karena oleh berkat dan rahmatnya sehingga penulis diberi kekuatan dan kesehatan dalam menjalankan penelitian, kemudian terima kasih diucapkan kepada Jim Wolter Maatuil S.Pd dan Adri Sasube S.th. selaku orang tua yang memberikan semangat, motivasi, dan biaya untuk melaksanakan penelitan, kemudian ke pada bapak Ir. Jacob L. A. Uktolseja M.Sc, Desti Christian Cahyaningrum S.Si., M.Si. selaku dosen pembimbing yang telah membantu berjalannya penelitian dan mengkoreksi tulisan sehingga layak untuk memenuhi syarat keulusan.

\section{References}

A. Aryani, Subandiyono \& T. Susilowati (2018). "Pemanfaatan Daun Turi (Sesbania Grandiflora) Yang Difermentasi Dalam Pakan Buatan Terhadap Pertumbuhan Ikan Mas (Cyprinus Carpio)," Journal of Aquaculture Management and Technology, 7(1), 1-9.

Bhaskar N, Suresh PV, Sakhare PZ, \& Sachindra NM. (2006). Shrimp biowaste fermentation with Pediococcus acidolactici CFR2182: Optimization of fermentation conditions by response surface methodology and effect of optimized conditions on deproteination/demineralization and carotenoid recovery. Enzyme and Microbial Technology 40: 1427-1434.

Elferink, S.J.W.H.O., Driehuis F, Gottschal JC, \& Spoelstra SF. (2010). Silage Fermentation Processes and Their Manipulation.

Fitri, D.S. (2013). Kemampuan Inokulum Serbuk Kering dari Cairan Terfermentasi Campuran Umbi Singkong (Manihot esculenta) dan Daun Turi (Sesbania grandiflora) untuk Meningkatkan Kualitas Silase Bahan Pakan Ikan Campuran Kedua Tumbuhan [Skripsi]. Salatiga: Fakultas Biologi Universitas Kristen Satya Wacana.

Hertanto Arif A.,Edy S., \& Dyanovita A. (2018). Penerapan Teknologi Silase "Fast-
Ferment" di Peternakan Kambing Lokal Kabupaten Lamongan. Jurnal Ternak, 09(01), pp 29.

Jamarun, N. I. Ryanto \& L. Sanda (2014). Pengaruh penggunaan berbagai bahan sumber karbohidrat terhadap kualitas silase pucuk tebu. Jurnal Peternakan Indonesia 16 (2), 114-118

Kung, L. and Shaver, R. (2001). Interpretation and use of silage fermentation analysis reports. J Focus on Forage 13(3).

Lelise, A., G. Belaynesh, M. Mulubrhan, S. Kedija, B. Endashaw \& B. Abebe. (2014). Isolation and screening of antibacterial producing lactic acid bacteria from traditionally fermented drinks ("Ergo and Tej") in Gondar town, Northwest Ethiopia. Global Research Journal of Public Health and Epidemiology 1(3): 18-22.

Masuko T, Hariyama Y, Takahashi Y, Cao LM, Goto M, \& Ohshima M. (2000). Effect of addition of fermented juice prepared from timothy and orchard grass on fermentation quality of silages. Asian-Australian Journal of Animal Sciences 13, Supplement B: 306-308.

Muck R. (1988). Factors influencing silage quality and their implications for management. Journal of Dairy Science 71: 2992-3002.

Oshima, M., Kimura, E., \& Yokota, H. (1997). A method of making good quality silage from direct cut alfalfa by spraying previously fermented juice. Anim Feed Scitech 66: 129-137.

Panda, C., U.S. Mishra, S. Mahapatra, \& G. Panigrahi (2013). Free radical scavenging activity and phenolic content estimation of Glinus oppositifolius and Sesbania grandiflora. Int. J. Pharm. 3(4): 722-727

Prayitno, A., H., Dadik, P., \& Budi, P. (2020). Buku Panduan Teknologi Silase. Politeknik Negri Jamber. 13-15. 
Ramli (2014). Pengaruh Inokulum Lactobacillus Plantarum 1A-2 dan 1BL-2 Terhadap Kualitas Silase Limbah Ikan Tuna (Thunnus atlanticus). Jurnal Ilmu Perikanan. 5(1), pp. 29.

R. Haryo Bimo Setiarto \& Nunuk Widhyastuti (2016). Penurunan Kadar Tanin Dan Asam Fitat Pada Tepung Sorgum Melalui Fermentasi Rhizopus oligosporus, Lactobacillus plantarum dan Saccharomyces cerevisiae. Jurnal Ilmuilmu Hayati. 15(2), 156-157.

Saun, R.J.V. and Heinrichs, A.J. (2008). Troubleshooting silage problems: How to identify potential problem. Proceddings of the Mid-Atlantic Conference; Pennsylvania, 26-26 May 2008. Penn State's Collage. hlm 2-10.

Skrede G, Storebakken T, Skrede A, Sahlstrøm S, Sørensen M, Shearer KD, \& Slinde E. (2002). Lactic acid fermentation of wheat and barley whole meal flours improves digestibility of nutrients and energy in Atlantic Salmon (Salmo salar L.) diets. Aquaculture 210: 305-321.

Skrede A, Sahlstrøm S, Ahlstrøm Ø, Connor KH, \& Skrede G. (2007). Effects of lactic acid fermentation and gamma irradiation of barley on antinutrient contents and nutrient digestibility in mink (Mustela vison) with and without dietary enzyme supplement. Archives of Animal Nutrition 61: 3, 211 221.

Wijayakusuma H. (2011). Manfaat Singkong Untuk Kesehatan. (http://www.singkong.net). Diakses pada 1 Januari 2020.

Zacharof, MP. \& RW. Lovitt (2012). Bacteriocins Produced by Lactic Acid Bacteria a Review Article. 3rd International Conference on Biotechnology and Food Science (ICBFS 2012). Bangkok, Thailand April 7-8, 2012. 2: 50-56.
Zakariah, M. (2014). Peran Bakteri Asam Laktat Dalam Proses Silase.(http://www.trobos.com/2014/detail berita.php?sid=4471\&sir=68). Diakses pada tanggal 30 Juli 2019. 